\title{
Effects of LY379268, A Selective Agonist of mGLu2/3 Receptors, on Isolation-Induced Aggression in Male Mice
}

\author{
José Francisco Navarro*, María Jesús Luque and Mercedes Martín-López
}

Department of Psychobiology. Faculty of Psychology. University of Málaga, Spain

\begin{abstract}
Recent studies indicate that glutamate metabotropic receptors (mGlu) 1 and 5 are involved in the regulation of aggressive behaviour. Brain distribution of mGlu2/3 receptors suggests that they may also play important roles in emotional responses, including aggression. This study examines the effects of LY379268 (0.25- $4 \mathrm{mg} / \mathrm{kg}$, ip), a selective agonist of the mGlu2/3 receptors, on agonistic interactions between male mice using an animal model of isolation-induced aggression. Individually housed mice were exposed to anosmic "standard opponents" 30 min after drug administration. Ten min of diadic interactions were staged between a singly housed and an anosmic mouse in a neutral area. The encounters were videotaped and the accumulated time allocated by subjects to ten broad behavioural categories was estimated using an ethologically based analysis. LY379268 (2 mg/kg) significantly reduced attack behaviour, as compared with the control group, without affecting immobility, whereas the highest dose of the drug $(4 \mathrm{mg} / \mathrm{kg})$ also decreased offensive behaviours (threat and attack), but with a marked increase of immobility (non-selective effect). These results indicate that mGlu2/3 receptors might be implicated in the modulation of aggression.
\end{abstract}

Keywords: Aggression, agonistic behaviour, metabotropic glutamate receptor, mGlu2/3 receptor, mice.

\section{INTRODUCTION}

Glutamate is the major excitatory neurotransmitter in the brain, with widespread projections and localization of its various receptors. It activates postsynaptic ligand-gated ion channel receptors (NMDA, AMPA and kainate receptors) as well as metabotropic glutamate (mGlu) receptors. mGlu receptors form a family of eight subtypes (mGlu1 to -8), which are conventionally subdivided into three groups on the basis of their amino acid sequence, pharmacological profile, and transduction pathways. Group I mGlu receptors (mGlu1 and mGlu5) are positively coupled to phospholipase C; group II mGlu receptors (mGlu2 and mGlu3) and group III mGlu receptors (mGlu4, mGlu6, mGlu7 and mGlu8) are negatively coupled to adenylyl cyclase. Moreover, group I receptors are located primarily post-synaptically in the brain whereas group II and III receptors are located primarily presynaptically and function as autoreceptors to decrease the excessive release of glutamate [1].

Aggressive behaviour is regulated by a variety of different neurotransmitter systems in the brain, such as serotonine $[2,3]$, dopamine $[4,5]$, GABA [6, 7], opiates [8], or gammahydroxybutyrate $[9,10]$. However, it is now recognized that aggression may be also influenced by glutamate system. Thus, studies of ionotropic receptors (NMDA and AMPA) indicate that glutamate neurotransmission plays a role in aggression [11-15]. By contrast, the role of mGlu receptors is less known. In recent studies, Navarro et al. $[16,17]$ found that the acute administration of MPEP (a selective antagonist of mGlu5 receptors) and JNJ16259685 (a selective

*Address correspondence to this author at the Department of Psychobiology, Faculty of Psychology, University of Málaga, Campus de Teatinos s/n, 29071 Málaga, Spain, Tel: 34 952132441; Fax: 34 952132621;

E-mail: navahuma@uma.es antagonist of mGlu1 receptors), produced a marked reduction of offensive behaviours (threat and attack) in male mice, suggesting a role for these receptors in aggression regulation. The brain distribution of $\mathrm{mGlu} 2 / 3$ receptors indicates that these receptors may also play important roles in emotional responses, including aggression. However, to date no studies have examined specifically the functional role of mGlu $2 / 3$ ligands in animal models of aggression. Therefore, the aim of this work was to analyze the effects of LY379268 $(0.25$, $0.5,1,2$, and $4 \mathrm{mg} / \mathrm{kg}$, ip), a selective agonist of the $\mathrm{mGlu} 2 / 3$ receptors, on agonistic interactions between male mice of the OF.1 strain. LY379268 is a potent metabotropic glutamate (mGlu) receptor agonist which selectively activates mGlu2/3 receptors with EC50 values in the low nanomolar range $\left(K_{\mathrm{i}}=14 \mathrm{nM}\right.$ and $5.8 \mathrm{nM}$ at human mGlu2 and mGlu3 receptors, respectively [18].

\section{MATERIALS AND METHODOLOGY}

\section{Animals}

A total of 154 albino adult male mice of the OF.1 strain weighing 25-30 g were used. Animals were housed under standardized lighting conditions (white lights on: 20:0008:00) at a constant temperature $\left(21^{\circ} \mathrm{C}\right)$ with food and tap water available ad libitum except during behavioural trials. Upon arrival in the laboratory, mice were allocated to two categories. Half were housed individually in transparent plastic cages $(24 \times 13.5 \times 13 \mathrm{~cm})$ to be used as experimental animals. All experimental subjects were isolated for 30 days prior to behavioural testing since this housing is an effective means of increasing the level of aggressiveness, particularly in laboratory mice [19]. The remainder were housed in groups of five to be used as "standard opponents". These animals were rendered temporally anosmic by intranasal lavage with $4 \%$ zinc sulphate solution (Sigma Laboratories) on both days 1 and 3 before testing. This type of opponent 
elicits attack but never initiates such behaviour [20]. Consequently, fighting is always unidirectional, and easily quantified.

\section{Drug Administration}

Six groups of mice were used. Animals were randomly allocated to one control group ( $\mathrm{n}=14$ each) receiving physiological saline, and five experimental groups ( $\mathrm{N}=12-14$ each) receiving LY379268 injections (Fig. 1). LY379268 (Tocris Laboratories) was diluted in physiological saline to provide appropriate doses for injections and administered in five doses: $0.25,0.5,1,2$ and $4 \mathrm{mg} / \mathrm{kg}$. The doses were chosen on the basis of recent behavioural studies using this compound in rodents [21,22]. Drug or vehicle was injected intraperitoneally in a volume of $10 \mathrm{ml} / \mathrm{kg}$.

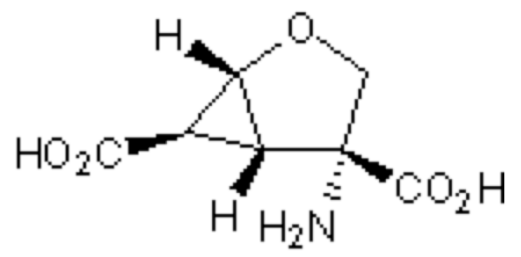

Fig. (1). (1R,4R,5S,6R)-4-Amino-2-oxabicyclo[3.1.0]hexane-4,6dicarboxylic acid.

\section{Behavioural Test}

Thirty minutes after injection, an isolated animal and a "standard opponent" were allowed to confront each other in a neutral area for $10 \mathrm{~min}$. This neutral cage consisted of an all-glass arena, measuring $50 \times 26 \times 30 \mathrm{~cm}$ with a fresh sawdust substrate. Before the encounter, the animals were allowed $1 \mathrm{~min}$ of adaptation to the neutral cage, whilst separated by means of a plastic barrier. The social encounters were videotaped using a Sony-V8 camera. All tests were conducted under red light between the second and seventh hours of the dark phase of the lighting condition. After each encounter, the neutral cage was washed and the sawdust bedding was replaced. The tapes were analyzed using a microprocessor and a custom-developed program [23], which facilitated estimating time and frequency allocated to ten broad behavioural categories. Only the behaviour of the isolated animal was assessed and the analysis was carried out by a trained experimenter 'blind' to the treatment administered to the experimental subjects. The categories and their constituent elements were as follows: (i) body care (including groom, self-groom, wash, shake, scratch); (ii) digging (dig, kick dig, push dig); (iii) non-social exploration (explore, rear, supported rear, scan); (iv) exploration from a distance (approach, attend, circle, head orient, stretched attention); (v) social investigation (crawl over, crawl under, follow, groom, head groom, investigate, nose sniff, sniff, push past, walk around); (vi) threat (aggressive groom, sideways offensive, upright offensive, tail rattle); (vii) attack (charge, lunge, attack, chase); (viii) avoidance/flee (evade, flinch, retreat, ricochet, wheel, startle, jump, leave, wall, clutch); (ix) defence/submission (upright defensive, upright submissive, sideways defensive), and (x) immobility (squat, cringe). This ethoexperimental procedure allows a complete quantification of the behavioural elements shown by the subject during the agonistic encounters.

\section{Data Analysis}

The medians for times allocated to each behavioural category were determined. Non-parametric Kruskal-Wallis tests were used to assess the variance of the behavioural measures in the different treatment groups. Subsequently, appropriate paired comparisons were carried out using Mann-Whitney U-tests to contrast behaviours in different treatment groups. The analysis was performed using nonparametric statistics, since criteria for parametric statistics were not met by the data.

This experiment was carried out in accordance with the guiding principles for care and use of Laboratory Animals approved by the European Communities Council Directive of November 24, 1986 (86/609/EEC).

\section{RESULTS}

The effects of acute administration of LY379268 on agonistic interactions between male mice are shown in Table 1 (medians with ranges). Kruskall-Wallis analysis showed that there was significant variance in the categories of digging $(\mathrm{p}<0.004)$, non social exploration $(\mathrm{p}<0.02)$, threat, attack and immobility $(\mathrm{p}<0.0001)$. Paired comparisons using Mann-Whitney U-tests revealed that LY379268 significantly reduced the time spent in digging behaviours $(2 \mathrm{mg} / \mathrm{kg}$ : $\mathrm{p}<0.05 ; 4 \mathrm{mg} / \mathrm{kg}: \mathrm{p}<0.001)$, threat $(4 \mathrm{mg} / \mathrm{kg}: \mathrm{p}<0.0001)$, attack $(2 \mathrm{mg} / \mathrm{kg}$ : $\mathrm{p}<0.025 ; 4 \mathrm{mg} / \mathrm{kg}$ : $\mathrm{p}<0.0001)$, and immobility $(4 \mathrm{mg} / \mathrm{kg}$ : $\mathrm{p}<0.01)$, in comparison with vehicle group. Non-social exploration behaviours were increased $(2 \mathrm{mg} / \mathrm{kg}$ : $\mathrm{p}<0.04 ; 4 \mathrm{mg} / \mathrm{kg}: \mathrm{p}<0.01$ ), as compared with vehicle group. The median values for the categories of avoidance/flee and defence/submission were zero for all groups.

\section{DISCUSSION}

In the last decade, the members of group II metabotropic glutamate (mGlu2/3) receptors have emerged as potential therapeutic targets. In fact, recent studies suggest that agonists of group II metabotropic glutamate (mGlu) receptors (mGlu2/3) have potential utility as novel therapeutic agents for treatment of different disorders such as anxiety schizophrenia, epilepsy, drug abuse or pain. Moreover, activation of group II mGluRs has been reported to be neuroprotective both in vitro and in vivo [24].

In rats, mGlu2 was highly and discretely expressed in cell bodies in almost all of the key regions of the limbic system in the forebrain. Likewise, presynaptic mGlu2 terminals have been found in most of the forebrain structures, especially in the lateral part of the central nucleus of the amygdala, and the CA1 region of the hippocampus. Although some overlaps exist, such as in the hippocampus and the amygdala, the expression of mGlu3 mRNA, however, appeared to be more disperse, compared with that of mGlu2 mRNA. These distribution results support previous behavioural studies that the mGlu $2 / 3$ receptors may play important roles in emotional responses [25].

mGlu2/3 receptors are presynaptic inhibitory autoreceptors that negatively modulate excitatory glutamate transmission. These receptors provide a negative feedback to keep glutamate transmission within the physiological range, preventing hyperexcitability from interfering with normal brain function [24]. LY379268 is a heterobicyclic amino acid and 
Table 1. Median Values (with Ranges) for Times (in Seconds) Allocated to Broad Behavioural Categories in Animals Receiving Acute Treatment with LY379268 (0.25 - $4 \mathrm{mg} / \mathrm{kg}$, ip)

\begin{tabular}{|c|c|c|c|c|c|c|}
\hline \multirow[b]{2}{*}{ Behavioural Categories } & \multirow[b]{2}{*}{ Vehicle } & \multicolumn{5}{|c|}{ Doses of LY $379268(\mathrm{mg} / \mathrm{kg})$} \\
\hline & & 0.25 & 0.5 & 1 & 2 & 4 \\
\hline Body care & $\begin{array}{c}6.7 \\
(0.9 .20 .1)\end{array}$ & $\begin{array}{c}4.1 \\
(2.4-21)\end{array}$ & $\begin{array}{c}5.6 \\
(2-20)\end{array}$ & $\begin{array}{c}5.5 \\
(0-20.4)\end{array}$ & $\begin{array}{c}5.9 \\
(0-15.1)\end{array}$ & $\begin{array}{c}6.8 \\
(0-37.7)\end{array}$ \\
\hline Digging $^{\text {a }}$ & $\begin{array}{c}12.6 \\
(0-28.5)\end{array}$ & $\begin{array}{c}17 \\
(0-57.9)\end{array}$ & $\begin{array}{c}4 \\
(0-64.4)\end{array}$ & $\begin{array}{c}4.2 \\
(0-60)\end{array}$ & $\begin{array}{c}0.5^{\mathrm{b}} \\
(0-29.7)\end{array}$ & $\begin{array}{c}0^{\mathrm{b}} \\
(0-45.5)\end{array}$ \\
\hline Non-social ${ }^{\text {a }}$ Exploration & $\begin{array}{c}474 \\
(386-536)\end{array}$ & $\begin{array}{c}462 \\
(431-531)\end{array}$ & $\begin{array}{c}453 \\
(390-529)\end{array}$ & $\begin{array}{c}476 \\
(435-574)\end{array}$ & $\begin{array}{c}518^{\mathrm{f}} \\
(442-565)\end{array}$ & $\begin{array}{c}537^{\mathrm{f}} \\
(275-565)\end{array}$ \\
\hline Exploration From a distance & $\begin{array}{c}6.8 \\
(2-11)\end{array}$ & $\begin{array}{c}7.5 \\
(1-27.3)\end{array}$ & $\begin{array}{c}7.1 \\
(1-51)\end{array}$ & $\begin{array}{c}11.9 \\
(1-26)\end{array}$ & $\begin{array}{c}11.1 \\
(2-21)\end{array}$ & $\begin{array}{c}6.6 \\
(4-34.5)\end{array}$ \\
\hline Social Investigation & $\begin{array}{c}8 \\
(0-60.3)\end{array}$ & $\begin{array}{c}14.2 \\
(0-108)\end{array}$ & $\begin{array}{c}16.8 \\
(0-57.3)\end{array}$ & $\begin{array}{c}8.5 \\
(0-90)\end{array}$ & $\begin{array}{c}8.7 \\
(0-34.5)\end{array}$ & $\begin{array}{c}13.5 \\
(1-56.7)\end{array}$ \\
\hline Threat $^{\mathrm{a}}$ & $\begin{array}{c}30.7 \\
(4-100)\end{array}$ & $\begin{array}{c}30.4 \\
(0-53)\end{array}$ & $\begin{array}{c}27 \\
(0-103)\end{array}$ & $\begin{array}{c}25 \\
(0-65.5)\end{array}$ & $\begin{array}{c}23.2 \\
(0-65)\end{array}$ & $\begin{array}{c}0^{\mathrm{c}} \\
(0-1)\end{array}$ \\
\hline Attack $^{a}$ & $\begin{array}{c}53.5 \\
(0-107)\end{array}$ & $\begin{array}{c}42.5 \\
(0-115)\end{array}$ & $\begin{array}{c}32.4 \\
(0-104)\end{array}$ & $\begin{array}{c}24.7 \\
(0-99)\end{array}$ & $\begin{array}{c}24^{\mathrm{d}} \\
(0-66)\end{array}$ & $\begin{array}{c}0^{\mathrm{d}} \\
(0-1)\end{array}$ \\
\hline Avoidance/flee & $\begin{array}{c}0 \\
(0-0)\end{array}$ & $\begin{array}{c}0 \\
(0-0.5)\end{array}$ & $\begin{array}{c}0 \\
(0-0.7)\end{array}$ & $\begin{array}{c}0 \\
(0-0)\end{array}$ & $\begin{array}{c}0 \\
(0.0)\end{array}$ & $\begin{array}{c}0 \\
(0-0.8)\end{array}$ \\
\hline Defence/Submission & $\begin{array}{c}0 \\
(0-0)\end{array}$ & $\begin{array}{c}0 \\
(0-0)\end{array}$ & $\begin{array}{c}0 \\
(0-0)\end{array}$ & $\begin{array}{c}0 \\
(0-0)\end{array}$ & $\begin{array}{c}0 \\
(0-0.9)\end{array}$ & $\begin{array}{c}0 \\
(0-0)\end{array}$ \\
\hline Immobility $^{\text {a }}$ & $\begin{array}{c}0 \\
(0-0)\end{array}$ & $\begin{array}{c}0 \\
(0-0)\end{array}$ & $\begin{array}{c}0 \\
(0-0)\end{array}$ & $\begin{array}{c}0 \\
(0-0)\end{array}$ & $\begin{array}{c}0 \\
(0-6.5)\end{array}$ & $\begin{array}{l}20.6^{\mathrm{e}} \\
(0-308)\end{array}$ \\
\hline
\end{tabular}

${ }^{a}$ Kruskal-Wallis test showed significant variance: $\mathrm{p}<0.02-\mathrm{p}<0.0001$.

${ }^{\mathrm{b}}$ Differs from vehicle on Mann-Whitney U tests: $\mathrm{p}<0.05-\mathrm{p}<0.0001$

${ }^{c}$ Differs from vehicle on Mann-Whitney U tests: $p<0.0001$.

${ }^{\mathrm{d}}$ Differs from vehicle on Mann-Whitney U tests: $\mathrm{p}<0.025-\mathrm{p}<0.0001$.

${ }^{\mathrm{e}}$ Differs from vehicle on Mann-Whitney U tests: $\mathrm{p}<0.01$.

${ }^{\mathrm{f}}$ Differs from vehicle on Mann-Whitney U tests: $\mathrm{p}<0.04-\mathrm{p}<0.01$.

selective mGlu2/3 receptor agonist. It is highly selective for the presynaptic mGlu2 and mGlu3 receptor subtypes as compared to other glutamate receptors including NMDA, AMPA, kainate, and other mGlu receptors [18].

The term agonistic behaviour encompasses threats and aggressive acts as well as defensive, submissive and flight behaviours. The ethological analyses of these social encounters seem to be an appropriate technique to distinguish between specific and non-specific drug-induced changes. As Table 1 indicates, LY379268 (2 and $4 \mathrm{mg} / \mathrm{kg}$ ) provoked a significant decrease of threat $(4 \mathrm{mg} / \mathrm{kg}$ ) and attack (2 and 4 $\mathrm{mg} / \mathrm{kg}$ ) behaviours in isolated male mice. However, whereas the dose of $2 \mathrm{mg} / \mathrm{kg}$ produced a selective reduction of attack, without affecting immobility, the highest dose of the drug (4 $\mathrm{mg} / \mathrm{kg}$ ) decreased offensive behaviours (threat and attack), but with a marked increase of immobility (non-selective effect). This suppression of motor activity has been described with high doses of LY379268 [22, 26, 27]. Furthermore, the reduction of aggressive behaviours was accompanied by an increase in non-social exploration as well as a decrease in digging behaviours ( 2 and $4 \mathrm{mg} / \mathrm{kg}$ ). Digging is involved in aggressive behaviour together with the threats and attacking behaviours. In fact, there is usually a correlation between these behavioural domains [28]. The antiaggressive action observed after treatment with LY379268 is in concordance with the results obtained by Lumley et al. [12], who found a reduced isolation-induced aggressiveness in mice following NAALADase inhibition, probably through increasing NAAG concentration in the brain and thus by increased activation of mGlu3 receptor.

Previous animal studies have indicated that drugs targeted at mGlu receptors could be useful for treatment of aggressive behaviour. Thus, mGlu1 and mGlu5 have been recently involved in aggression since the selective blockade of these receptors is associated with a notable decrease of offensive behaviours in male mice $[16,17]$. In conclusion, our results indicate that mGlu2/3 receptors might be also implicated in the modulation of aggression. Further studies with other selective ligands are needed to confirm these findings (such as LY354740 and NAAG).

\section{ABBREVIATIONS}

LY379268 = $(1 R, 4 R, 5 S, 6 R)-4$-Amino-2-oxabicyclo 


$$
\begin{array}{ll}
\text { NMDA } & \text { N-methyl-D-aspartate } \\
\text { AMPA } & \alpha \text {-Amino-3-hydroxy-5-methyl-4-isoxa- } \\
& \text { zolepropionate } \\
= & \text { Gamma-aminobutyric acid } \\
\text { GABA } & \text { 2-Methyl-6-(phenylethylnyl)pyridine } \\
\text { MPEP } & =3-4 \text {-Dihydro-2H-pyrano[2-3-b]quinolin-7- } \\
\text { JNJ16259685 } & \text { yl-(cis-4-methoxycyclohexyl)-methanone } \\
\text { DMSO } & \text { Dimethyl sulfoxide } \\
\text { NAALADase = } & \text { N-Acetylated- } \alpha \text {-linked acidic dipeptidase } \\
\text { NAAG } & \text { N-Acetylaspartyglutamate } \\
\text { LY354740 }= & (+)-2-\text { Aminobicyclo[3.1.0]hexane-2,6- } \\
& \text { dicarboxylic acid }
\end{array}
$$

\section{REFERENCES}

[1] Ferraguti, F.; Shigemoto, R. Metabotropic glutamate receptors. Cell Tissue Res., 2006, 326, 484-504.

[2] Bell, R.; Hobson, H. 5-HT1A receptor influences on rodent social and agonistic behaviour: a review and empirical study. Neurosci. Biobehav. Rev., 1994, 18, 325-338.

[3] Navarro, J.F.; Maldonado, E. Effects of acute, subchronic and intermittent MDMA ('ecstasy') administration on agonistic interactions between male mice. Aggress. Behav., 2004, 30, 84-91.

[4] Manzaneque, J.M.; Navarro, J.F. Behavioral profile of amisulpride in agonistic encounters between male mice. Aggress. Behav., 1999, $25,225-232$.

[5] Navarro, J.F.; Velasco, R.; Manzaneque, J.M. Acute and subchronic effects of pimozide on isolation-induced aggression in male mice. Prog. Neuropsychopharmacol. Biol. Psychiat., 2000, 24, 131-142.

[6] Martín-López, M.; Navarro, J.F. Behavioural profile of clobazam in agonistic encounters between male mice. Med. Sci. Res., 1996, 24, 89-91.

[7] Martín-López, M.; Navarro, J.F. Antiaggressive effects of zolpidem and zopiclone in agonistic encounters between male mice. Aggress. Behav., 2002, 28, 416-425.

[8] Espert, R.; Navarro, J.F.; Salvador, A.; Simón, V.M. Effects of morphine hydrochloride on social encounters between male mice. Aggressive Behav., 1993, 19, 377-383.

[9] Navarro, J.F.; Pedraza, C. An ethopharmacological assessment of the effects of gamma-hydroxybutyrate (GHB) on agonistic interactions in male mice. Med. Sci. Res., 1996, 24, 817-819.

[10] Navarro, J.F.; Pedraza, C.; González, F. Acute and subchronic effects of gamma-hydroxybutyrate on isolation-induced aggression in male mice. Methods Find. Exp. Clin. Pharmacol., 2007, 29, 379382.

[11] Belozertsseva, I.V.; Bespalov, A.Y. Effects of NMDA receptor channel blockade on aggression in isolated male mice. Aggress. Behav., 1999, 25, 381-396.

[12] Lumley, L.A.; Robinson, C.L.; Slusher, B.S.; Wozniak, K.; Dawood, M.; Meyerhoff, J.L. Reduced isolation-induced aggressiveness in mice following NAALADase inhibition. Psychopharmacology, 2004, 171, 375-381.

[13] Vekovischeva, O.Y.; Aitta-Aho, T.; Echenko, O.; Kankaanpaa, A.; Seppala, T.; Honkanen, A; Sprengel R.; Korpi, E.R. Reduced aggression in AMPA-type glutamate receptor GluR-A subunitdeficient mice. Genes Brain Behav., 2004, 3, 253-265.
[14] Shimshek, D.R.; Bus, T.; Grinevich, V.; Single, F.N.; Mack, V.; Sprengel, R.; Spergel, D.J.; Seeburg, P.H. Impaired reproductive behaviour by lack of GluR-B containing AMPA receptors but not of NMDA receptors in hypothalamic and septal neurons. Mol. Endocrinol., 2006, 20, 219-231.

[15] Navarro, J.F.; Burón, E.; Martín-López, M. Antiaggressive effects of topiramate in agonistic encounters between male mice. Methods Find. Exp. Clin. Pharmacol., 2007, 29, 195-198.

[16] Navarro, J.F.; Postigo, D.; Martín-López, M.; Burón, E. Antiaggressive effects of MPEP, a selective antagonist of mGlu5 receptor, in agonistic interactions between male mice. Eur. J. Pharmacol., 2006, 551, 67-70.

[17] Navarro, J.F.; De Castro, V.; Martín-López, M. JNJ16259685, a selective mGlu1 antagonist, suppresses isolation-induced aggression in male mice. Eur. J. Pharmacol., 2008, 586, 217-220.

[18] Monn, J.A.; Valli, M.J.; Massey, S.M.; Hansen, M.M.; Kress, T.J. Wepsiec, J.P.; Harkness, A.R.; Grutch, J.L. Jr.; Wright, R.A.; Johnson, B.G.; Andis, S.L.; Kingston, A.; Tomlinson, R.; Lewis, R.; Griffey, K.R.; Tizzano, J.P.; Schoepp, D.D. Synthesis, pharmacological characterization, and molecular modeling of heterobicyclic amino acids related to (+)-2-aminobicyclo[3.1.0]hexane-2,6dicarboxylic acid (LY354740): Identification of two new potent, selective, and systemically active agonists for group II metabotropic glutamate receptors. J. Med. Chem., 1999, 42, 10271040.

[19] Navarro, J.F. An ethoexperimental analysis of the agonistic interactions in isolated male mice: Comparison between OF.1 and NMRI strains. Psicothema, 1997, 9, 333-336.

[20] Brain, P.F.; Benton, D.; Childs, G.; Parmigiani, S. The effects of the type of opponent in test of murine aggression. Behav. Processess, 1981, 6, 319-327.

[21] Sharpe, E.F.; Kingston, A.F.; Lodge, D.; Monn, J.A.; Headley, P.M. Systemic pre-treatment with a group II mGlu agonist, LY379268, reduces hyperalgesia in vivo. Br. J. Pharmacol., 2002, $135,1255-1262$.

[22] Woolley, M.L.; Pemberton, D.J.; Bates, S.; Corti, C.; Jones, D.N The mGlu2 but not the mGlu3 receptor mediates the actions of the mGluR2/3 agonist, LY379268, in mouse models predictive of antipsychotic activity. Psychopharmacology, 2008, 196, 431-440.

[23] Brain, P.F.; McAllister, K.H.; Walmsey, S. Drug effects on social behaviour: methods in ethopharmacology. In: Boulton, A.A.; Baker, G.B.; Greenshaws, A.J.; Eds.; Neuromethods. Humana Press: New Jersey, 1989, 687-739.

[24] Imre, G. The preclinical properties of a novel group II metabotropic glutamate receptor agonist LY379268. CNS Drug Rev., 2006, 13, $1-21$.

[25] Gu, G.; Lorrain, D.S.; Wei, H.; Cole, R.L.; Zhang, X.; Daggett, L.P.; Schaffhauser, H.J.; Bristow, L.J.; Lechner, S.M. Distribution of metabotropic glutamate 2 and 3 receptors in the rat forebrain: Implication in emotional responses and central disinhibition. Brain Res., 2008, 1197, 47-62.

[26] Cartmell, J.; Monn, J.A.; Schoepp, D.D. The metabotropic glutamate 2/3 receptor agonists LY354740 and LY379268 selectively attenuate phencyclidine $v s$ d-amphetamine motor behaviours in rats. J. Pharmacol. Exp. Ther., 1999, 291, 161-170.

[27] Cartmell, J.; Monn, J.A.; Schoepp, D.D. Tolerance to the motor impairment, but not to the reversal of PCP-induced motor activities by oral administration of the mGlu2/3 receptor agonist, LY379268. Naunyn. Schmiedeberg 's Arch. Pharmacol., 2000, 361, 39-46.

[28] Kudryavtseva, N.N.; Bondar, N.P.; Alekseyenko, O.V. Behavioral correlates of learned aggression in male mice. Aggress. Behav., 2000, 26, 386-400. 